\title{
Abusive yet affectionate husbands: Conflicting perceptions of domestic violence experiences of wives living in urban slum communities of Mumbai, India
}

\author{
Ajeesh Sebastian, Shahina Begum*, Balaiah Donta, D. D. Naik, Prashant Tapase
}

Department of Biostatistics, ICMR- National Institute for Research in Reproductive Health, Parel, Mumbai, Maharashtra, India

Received: 18 July 2017

Accepted: 18 August 2017

\section{*Correspondence:}

Dr. Shahina Begum,

E-mail: begums@nirrh.res.in

Copyright: () the author(s), publisher and licensee Medip Academy. This is an open-access article distributed under the terms of the Creative Commons Attribution Non-Commercial License, which permits unrestricted non-commercial use, distribution, and reproduction in any medium, provided the original work is properly cited.

\section{ABSTRACT}

Background: The prevalence of intimate partner violence (IPV) contributed to reproductive health problems worldwide. Data on coping mechanism of women within domestic violence (DV) were unexplored.

Methods: The objective of the paper was to explore the perceived cause of DV and coping mechanism of women who reported affectionate nature of husband. A community-based intervention study was carried out in urban slums to screen women with an unmet need for family planning. Women reported of DV in the past one year preceding the survey were counselled on marital communication and family planning methods. During these sessions, women shared their views on the cause of DV and their coping mechanism.

Results: The narratives of the sessions threw light into the cause of DV, which includes decision-making, the influence of significant others and fewer time couples spent with each other. Affectionate nature and violence by husbands created a conflict of emotions. Fear of loss of the relationship and socio-cultural attitude made them remain in the relationship.

Conclusions: The wives develop an emotional attachment with their partners and do not want to leave the relationship. They create a space within the abusive relationship; enjoy limited functionings, a bonus of affections and demoting violence from the partner without taking a chance to lose the relationship.

Keywords: Abusive vs. affection, Conflict of emotions, Coping strategies, Domestic violence, Emotional attachment

\section{INTRODUCTION}

The prevalence of intimate partner violence (IPV) is a threat to public and reproductive health globally. As per National Crime Record Bureau statistics, violence by the husband or his relatives accounted for one-third of the total crimes against women in India. Between 2010 and 2015 , there was a reported annual growth rate $4.11 \%$ of crimes against women and in Maharashtra, it was recorded $2.77 \%$ total growth in five years. ${ }^{1}$ National Family Health Survey 3 and 4 data reveal that spousal violence was decreased from $30.7 \%$ to $21.4 \%$ in Maharashtra over a period of 10 years. $^{2}$

Several Interventional and national cross-sectional studies have shown the prevalence of violence, its risk factors and consequences on the overall health of women. ${ }^{3-14}$ Very few qualitative studies discussed the relationship dynamics between the abusive husband and wife. ${ }^{15-20}$ Studies from developing countries demonstrated that the women experienced a conflict of emotions and developed coping mechanisms. They did not want to 
leave their abusing partners due to patriarchal society, financial dependency on husbands, fear and considering violence as normal behaviour. ${ }^{18-21}$ In India, data on coping mechanism within DV were unexplored. The objective of the study was to find out the trigger point of DV and coping strategies among women who had experienced DV by their affectionate husbands.

\section{METHODS}

A community-based intervention study was carried out in two urban slums namely Kajupada and Tunga village of Mumbai. The baseline survey was conducted among 1136 women who were currently married; aged 18-39 years; staying with their husbands; having at least one child and unmet need for family planning methods. The samples were selected using systematic random sampling. Information on background characteristics, type of DV faced, access and utilization of family planning methods, decision-making power of the sample population were collected using structured questionnaire. Out of 1136, a total of 181 women had experienced DV during baseline survey. Trained Social Workers/Psychologist provided one session on family planning and three counselling sessions on marital communication to these women within interval of at least 15 days. During the session, women were able to disclose and describe nature of their husbands, causes of DV and their coping mechanisms. Out of the total, 20 women had given contradictory narrations about their husband's nature such as their abusive behaviour and affectionate nature. The present study used mixed method approach to fulfil the objective. Quantitative data from baseline survey were used to highlight the demographic characteristics, frequency, and type of violence, and decision-making power of the 20 samples whereas the qualitative data had been taken from the narratives recorded during the four counselling sessions at the interval of at least two weeks. SPSS 16 was used for the quantitative data analysis and the qualitative data was analysed manually. The analysis was divided into two broad themes as perceived factors influencing the violence and coping mechanisms.

\section{RESULTS}

\section{Background characteristics of women}

The majority of women were younger ( $<25$ years), Hindu, educated, housewives and living in a nuclear family (Table 1). Majority of their husbands were younger ( $<35$ years), literate and unskilled workers (Table 2).

Table 3 describes the nature of violence experienced by the women for the last 12 months preceding the survey. Slapping, humiliating in front of others, insulting to make one feel bad about oneself, twisting arms or pulling hair and kicking or beating up were common practice by husbands. Seven out of 10 women had also experienced the sexual violence.

Table 1: Socioeconomic and demographic characteristics of women.

\begin{tabular}{|l|l|}
\hline Characteristics of respondents & Number \\
\hline Age (years) & \\
\hline $20-25$ & 10 \\
\hline $26-30$ & 7 \\
\hline $31-35$ & 3 \\
\hline Education level & \\
\hline High school & 2 \\
\hline Primary and middle school & 13 \\
\hline Illiterate & 5 \\
\hline Religion & \\
\hline Hindu & 15 \\
\hline Muslim & 5 \\
\hline Age at marriage (years) & \\
\hline$<18$ & 7 \\
\hline$\geq 18$ & 13 \\
\hline Years in a marital relationship & \\
\hline$\leq 5$ years & 8 \\
\hline $6-10$ years & 8 \\
\hline $11-15$ & 2 \\
\hline$>15$ & 2 \\
\hline Type of family & 8 \\
\hline Joint family & 12 \\
\hline Nuclear family & 2 \\
\hline Occupation & 18 \\
\hline Employed & \\
\hline Housewife & \\
\hline
\end{tabular}

Table 2: Demographic characteristics of the husbands.

\begin{tabular}{|l|l|}
\hline Characteristics of husbands & Number \\
\hline Age (years) & \\
\hline $25-29$ & 8 \\
\hline $30-34$ & 8 \\
\hline$\geq 35$ & 4 \\
\hline Education status (Attended school) & \\
\hline Literate & 19 \\
\hline Illiterate & 1 \\
\hline Occupation & \\
\hline Skilled worker & 12 \\
\hline Unskilled worker & 2 \\
\hline Professional & 3 \\
\hline Small business & 3 \\
\hline
\end{tabular}

In-depth analysis showed that four women had experienced all three forms of violence whereas emotional and physical violence experienced by six women, emotional and sexual violence by four women and physical and sexual by five women. This categorization also did not show a significant relationship between the coupled occurrences of different types of violence. 
Table 3: Nature and frequency of violence in the past 12 months preceding the survey.

\begin{tabular}{|c|c|c|c|}
\hline \multirow{2}{*}{$\begin{array}{l}\text { The nature of } \\
\text { violence }\end{array}$} & \multicolumn{2}{|c|}{$\begin{array}{l}\text { during the last } 12 \\
\text { months }\end{array}$} & \multirow{2}{*}{$\begin{array}{l}\text { Frequency } \\
n=20\end{array}$} \\
\hline & Often & Sometimes & \\
\hline \multicolumn{4}{|l|}{ Emotional violence } \\
\hline $\begin{array}{l}\text { Humiliation in } \\
\text { front of others }\end{array}$ & 3 & 7 & 10 \\
\hline $\begin{array}{l}\text { Threaten to hurt or } \\
\text { harm }\end{array}$ & 1 & 2 & 3 \\
\hline Insulting & 3 & 5 & 8 \\
\hline \multicolumn{4}{|l|}{ Physical violence } \\
\hline Slapping & 5 & 7 & 12 \\
\hline $\begin{array}{l}\text { Twist the arms or } \\
\text { pull the hair }\end{array}$ & 3 & 2 & 5 \\
\hline $\begin{array}{l}\text { Push, shake or } \\
\text { throw something }\end{array}$ & 2 & 1 & 3 \\
\hline $\begin{array}{l}\text { Punch with fist or } \\
\text { with something }\end{array}$ & 2 & 1 & 3 \\
\hline Kick, drag or beat up & 3 & 1 & 4 \\
\hline \multicolumn{4}{|l|}{ Sexual violence } \\
\hline $\begin{array}{l}\text { Physically force to } \\
\text { sexual intercourse } \\
\text { when did not want to }\end{array}$ & 1 & 4 & 5 \\
\hline $\begin{array}{l}\text { Force to perform } \\
\text { any sexual acts } \\
\text { women did not } \\
\text { want to }\end{array}$ & 1 & 1 & 2 \\
\hline
\end{tabular}

\section{Narration on abusive yet affectionate husband}

The researchers inquired the nature of the husbands excluding the abusive behaviour. They reported good qualities of their husbands, which includes "very loving and caring" (case no. 2226, 2561, 3863, 1945, 732, 12, 3984, 2736, 2528, 2790), "taking care of her and children" (case no. 2226), "very good and caring" (case no. 2643, 1093, 2228), "understanding and caring" (case no. 1715), "taking care of household responsibilities" (case no. 2643, 2561, 732, 2736), “understanding” (case no. 2643), "takes care of health problem" (case no. 2643), "have good relations with" (case no. 3863, 1945, 969, 2304, 12, 1715, 593, 2790), “good person" (case no. 969, 2528, 2485), "very nice and caring" (case no. 2304), "very much caring and understanding (her) feelings" (case no. 593), "looking after all family members" (case no. 3046), "understanding her mood and handle accordingly" (case no. 2528). There were repeated uses of the words such as love, care, good, taking responsibilities, and understanding. One of the women even justified wife beating; Yes. My husband slaps me sometimes. Every man does so. But he loves me too case no. 2561). One woman had revealed that even though her husband was affectionate, she did not like his dominating behaviour (case no. 1945).

\section{Factors influencing the abusive relationship}

Quality of time spent together: Couples did not know about the likes and dislikes of each other even after more than five years of married life due to lack of time spent together. A majority of the husbands were working in the informal sector (Table 2) which indicates long working hours (petty business, tailoring, buffing etc) and reaching home late. "He is not giving time to her due to his nature of work" (case no. 12) or he is a truck driver, and he had to go out of the city for 2-3 days. "He is not giving me time due to his work and friends. He used to come late from work and go to meet his friends in the community. Hence, we talk less and fight more when we come together" (case no. 3863). Even if couples were together, men often ignored the emotional needs of the women and demanded sex. The refusal of sex from wives led to rage and DV.

Influence of family members: The family members played an important role in the marital relationship especially living in joint family. One respondent stated the lack of space within the joint family. "We don't get time to stay with each other because of the joint family and lack of space" (case no. 2132). The wives frequently complained about the influence of in-laws in creating issues that led to DV (case no. 969, 1093, 2228, 2485). "He is a good person. He loves me. But his relatives are always trying to create problems between us" (case no. 2304). Another woman stated the burden of "verbal abuse by in-laws" (case no. 2228). Family members forced the husband to restrict the freedom of mobility of wives. Further, religious belief regarding the use of family planning methods (case no. 2226,2736, 2485,1945 ) or desire for a baby boy by husband and family members against her will led to violence.

Table 4: Decision-making power.

\begin{tabular}{|c|c|c|c|c|c|}
\hline Indicators for decision-making & Type of family & Self/Both & Husband & Others including family members & Number \\
\hline \multirow{2}{*}{$\begin{array}{l}\text { Decisions about health care for } \\
\text { yourself }\end{array}$} & Joint family & 2 & 3 & 3 & 8 \\
\hline & Nuclear family & 4 & 6 & 2 & 12 \\
\hline \multirow{2}{*}{$\begin{array}{l}\text { Decision about daily household } \\
\text { purchases }\end{array}$} & Joint family & 2 & 3 & 3 & 8 \\
\hline & Nuclear family & 3 & 7 & 2 & 12 \\
\hline \multirow{3}{*}{$\begin{array}{l}\text { Decision about visits to your } \\
\text { family or relatives }\end{array}$} & Joint family & 2 & 3 & 3 & 8 \\
\hline & Nuclear family & 3 & 7 & 2 & 12 \\
\hline & & 16 & 29 & 15 & \\
\hline
\end{tabular}


It is clear from the Table 4 that other family members played a significant role in decision making even if respondents were living in a nuclear family. Though the decision power favoured the husbands irrespective of the type of family; joint decisions (self or with husband) were reported by few women either living in a nuclear or joint family.

\section{The coping strategies}

Women were coping with DV in two ways either accepting or objecting/opposing. One group (11 women) had subjugated themselves to the demands of their husband so that no further provocation to DV. The violence made the women feel "tensed" (case no. 2561, 2485), "silent" (case no. 2561), "not to love her husband" (case no. 3984), and "upset" (case no. 3046). The other group ( 9 women) used to oppose themselves against the violence and got into a quarrel with them. The violence made them "angry" (case no. 1093, 3863, 1945, $1715,2736,2528)$. It was also found in a few cases that if the influence of other family members was more, wives constantly urged their husbands to move out of the joint family because of DV caused by other members of the family. Once the couples moved out of the joint family, women experienced peace at home, even if they experienced IPV sometimes.

It was noticed that, except one, all 19 women would like not to break up their marriages. They hope that things were not so bad. The affectionate part of husbands outweighed the abusive part. Further, a majority of them were housewives, and financially dependent on their husbands. Also for the sake of children, women found it difficult to break the familial responsibilities.

\section{DISCUSSION}

The 20 cases were purposefully selected from the community-based study conducted in Mumbai urban slum areas. The study concentrated on analysing the nature of violence, its underlying causes, and coping mechanism of women towards the violence.

The demographic characteristics of the women were associated with the risk of violence. Studies have reported about the prevalence of IPV among women with low socio-economic and demographic profiles such as urban residence, lower education, and lower family income. ${ }^{6,13,22-27}$ The majority of them were housewives and financially dependent upon husbands which put them under the risk of violence. In-laws' interferences, decision-making process by husband and other family members and less time spent with each were factors contributed to DV.

Women adopted various coping strategies to deal with DV. The violence made them angry and they opposed themselves against the violence and got into a quarrel with husband and family members. The experience of violence over a longer period had influenced them to think DV as normal behaviour or IPV is normal in relationship. ${ }^{28,29}$ They accepted DV as part of the marital life because of the perception of, fear of loss of the marital relationship and society's rejection. ${ }^{29-32}$ The same perceptions had observed in the present study also. Women reported about evidence of relatively satisfied relationships too. ${ }^{33}$ In-depth analysis showed that wives reported the other side of husband's nature as good, loving, caring which outweighed the abusive part of their husbands. We also observed that the women tried to find out the solution to prevent DV. If the DV was triggered because of in-laws or other family members, women tried to motivate their husbands to move out of joint family. The new home enabled them to make improved decisionmaking power and spent more time with their husbands. ${ }^{34,35}$

The women who did not find leaving their husbands as a solution to their problem might be due to children to take care of, deep-rooted values and culture, affectionate husband, financial dependency and patriarchal society. ${ }^{35-}$ 37

\section{CONCLUSION}

The wives develop an emotional attachment with their partners and do not want to leave the relationship due to their lack of capabilities, fear for society's rejection of leaving the relationship. They create a space within the abusive relationship; enjoy limited functionings, a bonus of affections and demoting violence from the partner without taking a chance to lose the relationship.

\section{ACKNOWLEDGMENTS}

Authors are grateful to Indian Council of Medical Research New Delhi for funding the study (Project ID No: 206/2012). In addition, authors also acknowledge the contribution of Dr. Prakasham CP, and Dr. Saritha Nair, ICMR-NIMS, New Delhi in this project. Authors thank all the project staff and participants in the study.

\section{Funding: Indian Council of Medical Research (Project ID No.: 206/2012) \\ Conflict of interest: None declared \\ Ethical approval: NIRRH Ethics Committee for Clinical Studies (D/ICEC/Sci-25/32/2012)}

\section{REFERENCES}

1. National Crime Records Bureau. Crime in India: Additional Tables. Available at http://ncrb.nic.in/StatPublications/CII/CII2015/CII_ Additional_Tables_2015/ADDITIONAL_TABLES. htm. Accessed on 15/05/2017.

2. International Institute for Population Sciences. National Family Health Survey 2015-16: state fact sheet - Maharashtra. Available at 
http://rchiips.org/NFHS/pdf/NFHS4/Maharashtra.pd. Accessed on 15/06/2017.

3. Bushra S, Campbell JC. Intimate partner violence against women in slums in India. Indian J Med Res. 2015;141(6):757-60.

4. Kamimura A, Ganta V, Myers K, Thomas T. Intimate partner violence and physical and mental health among women utilizing community health services in Gujarat, India. BMC Women's Health. 2014; 14:127-38.

5. Das S, Bapat U, Shah More N, Alcock G, Joshi W, Pantvaidya $S$ et al. Intimate partner violence against women during and after pregnancy: A cross-sectional study in Mumbai slums. BMC Public Health. 2013;13:817.

6. Begum S, Donta B, Nair S, Prakasam CP. Sociodemographic factors associated with Domestic Violence in urban slums, Mumbai, Maharashtra, India. Indian J Med Res. 2015;141:783-8.

7. Warshaw C, Brashler P, Gil J. Mental Health Consequences of Intimate Partner Violence. In: Mitchell C, Anglin D, eds. Intimate Partner Violence: A Health-Based Prespective. New York: Oxford University Press; 2009:147-71.

8. Kamimura A, Christensen N, Tabler J, Ashby J, Olson LM. Prevalence of intimate partner violence and its impact on health: Female and male patients using a free clinic. J Health Care Poor Underserved. 2014;25(2):731-45.

9. Chandra PS, Satyanarayana VA, Carey MP. Women reporting intimate partner violence in India: Associations with PTSD and depressive symptoms. Arch Wom Ment Health. 2009;12(4):203-9.

10. Weiss HA, Patel V, West B, Peeling RW, Kirkwood BR, Mabey D. Spousal sexual violence and poverty are risk factors for sexually transmitted infections in women: A longitudinal study of women in Goa, India. Sex Transm Infect. 2008;84(2):133-9.

11. Daruwalla N, Fernandez A, Salam J, Shaikh N, Osrin D. Conflict, Crisis, and Abuse in Dharavi, Mumbai: Experiences from Six Years at a Centre for Vulnerable Women and Children. PLoS Medicine. 2009;6(7):e1000088.

12. Khot A, Menon S, Dilip T. Domestic violence: Levels, correlates, causes, impact, and response. A community based study of married women from Mumbai slums. Mumbai: Centre for Enquiry into Health and Allied Themes; 2004.

13. Mahapatro M, Gupta R, Gupta V. The risk factor of Domestic Violence in India. Indian $\mathrm{J}$ Community Med. 2012;37(3):153-7.

14. Dalal K, Lindqvist K. A national study of the prevalence and correlates of Domestic Violence among women in India. Asia Pac J Public Health. 2012;24(2):265-77.

15. Hayati EN, Eriksson M, Hakimi M, Högberg U, Emmelin M. Elastic band strategy: Women's lived experiences of coping with Domestic Violence in rural Indonesia. Global Health Action. 2013;6:10.3402/gha.v6i0.18894.
16. Hayati EN, Högberg U, Hakimi M, Ellsberg MC, Emmelin M. Behind the silence of harmony: Risk factors for physical and sexual violence among women in rural Indonesia. BMC Womens Health. 2011;11:52.

17. Childress S. A meta-summary of qualitative findings on the lived experience among culturally diverse Domestic Violence survivors. Issues Ment Health Nurs. 2013;34(9):693-705.

18. Rusbult CE, Martz JM. Remaining in an Abusive Relationship: An Investment Model Analysis of Nonvoluntary Dependence. Personality Soc Psychol Bull. 1995;21(6):558-571.

19. Barnett OW. Why Battered Women Do Not Leave, Part 1. Trauma Violence Abuse. 2000;1(4):343-72.

20. Barnett OW. Why Battered Women Do Not Leave, Part 2. Trauma Violence Abuse. 2001;2(1):3-35.

21. Colucci E, Hassan G. Prevention of Domestic Violence against women and children in low-income and middle-income countries. Curr Opin Psychiatry. 2014;27(5):350-7.

22. Donta B, Nair S, Begum S, Prakasam CP. Association of Domestic Violence From Husband and Women Empowerment in Slum Community, Mumbai. J Interpers Violence. 2016;31(12):2227-39.

23. Babu BV, Kar SK. Domestic Violence against women in eastern India: A population-based study on prevalence and related issues. BMC Public Health. 2009;9:129.

24. Borah PK, Kundu AS, Mahanta J. Dimension and Socio-demographic Correlates of Domestic Violence: A study from Northeast India. Community Ment Health J. 2017;53(4):496-9.

25. George J, Nair D, Premkumar NR, Saravanan N, Chinnakali P, Roy G. The prevalence of Domestic Violence and its associated factors among married women in a rural area of Puducherry, South India. J Fam Med Prim Care. 2016;5(3):672-6.

26. Sinha A, Mallik S, Sanyal D, Dasgupta S, Pal D, Mukherjee A. Domestic violence among ever married women of reproductive age group in a slum area of Kolkata. Indian $\mathbf{J}$ Public Health. 2012;56(1):31-6.

27. Chibber KS, Krupp K, Padian N, Madhivanan P. Examining the determinants of sexual violence among young, married women in Southern India. J Interpersonal Violence. 2012;27(12):2465-83.

28. Dutton DG, Painter S. Emotional attachments in abusive relationships: A test of traumatic bonding theory. Violence Victims. 1993;8(2):105-20.

29. Sharma KK, Vatsa M. Coping strategies adopted by nurses experiencing domestic violence by their marital partners. Nurs J India. 2014;105(1):11-4.

30. Jejeebhoy SJ. Associations between wife-beating and fetal and infant death: Impressions from a survey in rural India. Stud Fam Plann. 1998;29: 300-8.

31. Narayana G. Family violence, sex and reproductive health behavior among men in uttar pradesh, india. Presentation to the National Council for International 
Health Conference. Crystal City, Virginia. June, 1996.

32. Kaur R, Garg S. Addressing domestic violence against women: an unfinished agenda. Indian J Community Medic: Official Public Indian Association of Preven Soc Medic. 2008;33(2):73-6.

33. Williams SL, Frieze IH. Patterns of violent relationships, psychosocial distress, and marital satisfaction in a national sample of men and women. Sex Roles. 2005;52:771-84.

34. Kabeer N. Reflections on the measurement of women's empowerment. In: SIDA, ed. Discussing women's empowerment-theory and practice. Stockholm: SIDA studies no. 3; 2001a:17-54.

35. Malhotra A, Schuler SR. Women's empowerment as a variable in international development. In: Narayan
D, ed. measuring empowerment: cross-disciplinary perspectives. Washington, DC: The World Bank;2005:71-88.

36. Fraser H. Women, love, and intimacy 'gone wrong': Fire, wind and ice. Affilia. 2005;20:10-20.

37. Jejeebhoy SJ. Wife-beating in rural India: A husband's right? evidence from survey data. Econo Political Weekly. 1998;33(15):855-62.

Cite this article as: Sebastian A, Begum S, Donta B, Naik DD, Tapase P. Abusive yet affectionate husbands: conflicting perceptions of domestic violence experiences of wives living in urban slum communities of Mumbai, India. Int J Reprod Contracept Obstet Gynecol 2017;6:4413-8. 